\title{
Carbonyl sulfide in air extracted from a South Pole ice core: a 2000 year record
}

\author{
M. $\operatorname{Aydin}^{1}$, M. B. Williams ${ }^{1, *}$, C. Tatum ${ }^{1, * *}$, and E. S. Saltzman ${ }^{1}$ \\ ${ }^{1}$ Department of Earth System Science, University of California, Irvine, California, USA \\ *now at: NASA Ames Research Center, Moffett Field, California, USA \\ *** now at: University of Miami, Florida, USA
}

Received: 4 July 2008 - Published in Atmos. Chem. Phys. Discuss.: 3 September 2008

Revised: 25 November 2008 - Accepted: 25 November 2008 - Published: 17 December 2008

\begin{abstract}
In this study, we present carbonyl sulfide (COS) measurements from an ice core drilled near South Pole, East Antarctica (SPRESSO). The samples are from 135$291 \mathrm{~m}$, with estimated mean COS ages ranging from 278 to 2155 years before present (defined as 2000 C.E.). When combined with the previous records of COS from Antarctic ice cores and firn air, the current data provide a continuous record of COS extending beyond the last two millennia. The general agreement between ice cores, firn air, and modern air measurements supports the idea that polar ice is a valid archive for paleoatmospheric COS. The average COS mixing ratio of the SPRESSO data set is $(331 \pm 18) \mathrm{ppt}$ (parts per trillion in $\mathrm{mol} / \mathrm{mol}, \pm 1 \sigma, n=100$ ), excluding 6 outliers. These data confirm earlier firn air and ice core measurements indicating that the late 20th century COS levels of $500 \mathrm{ppt}$ are greatly increased over preindustrial levels and represent the highest atmospheric levels over the past 2000 years. The data also provide evidence of climate-related variability on centennial time-scales, with relative maxima at the peaks of Medieval Climate Anomaly and Little Ice Age. There is evidence for a long-term increasing trend in COS of 1.8 ppt per 100 years. Further ice core studies will be needed to determine whether this trend reflects secular variability in atmospheric COS, or a slow post-depositional chemical loss of COS in the ice core.
\end{abstract}

\section{Introduction}

Carbonyl sulfide (COS) is a long-lived sulfur gas with an average mixing ratio of $450-500 \mathrm{ppt}$ (parts per trillion as $\mathrm{mol} / \mathrm{mol}$ ) in the troposphere (Bandy, 1992; Griffith et al.,

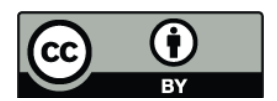

Correspondence to: M. Aydin

(maydin@uci.edu)
1998; Mahieu et al., 2003; Mihalopoulos et al., 1991; Montzka et al., 2007; Rinsland, 2002; Schneider, 2002; Xu, 2000). The atmospheric chemistry of COS has drawn attention because of its role as a precursor for stratospheric sulfate, particularly during periods of volcanic quiescence (Crutzen, 1976; Turco et al., 1980). There is some debate regarding the importance of COS compared to other stratospheric sulfate precursors such as $\mathrm{SO}_{2}$ and DMS (Golombek and Prinn, 1993; Hofmann, 1990; Sedlecek et al., 1983; Thomason et al., 1997). Most models and budgetary mass balance calculations indicate that COS emissions cannot solely account for background levels of stratospheric sulfate aerosol (Chin and Davis, 1995; Kjellström, 1998; Myhre et al., 2004; Pitari et al., 2002; Weisenstein et al., 1997) as supported by sulfur isotope measurements of stratospheric sulfate aerosol (Leung et al., 2002). It has also been shown that COS at the tropical tropopause can reach levels comparable to the tropospheric mixing ratios, most likely as a result of convective uplift of biomass burning plumes (Barkley et al., 2008; Notholt et al., 2003). Most recent assessments of stratospheric aerosols properties suggest that $\mathrm{COS}$ and $\mathrm{SO}_{2}$ contribute equally to the stratospheric sulfate budget during volcanically quiescent periods, with the COS contribution possibly being the dominant source above $25 \mathrm{~km}$ (Weisenstein and Bekki et al., 2006).

There have been several reviews of the COS budget (Chin and Davis, 1993; Kettle et al., 2002; Khalil and Rasmussen, 1984; Watts, 2000). The sources of tropospheric COS include direct terrestrial and oceanic emissions of COS and production in the atmosphere from the oxidation of carbon disulfide $\left(\mathrm{CS}_{2}\right)$ and dimethyl sulfide (DMS) (Barnes et al., 1994; Chin, 1991; Patroescu et al., 1999). The oceans are both a source and sink of atmospheric COS, with strong latitudinal and seasonal dependence, and a net air/sea flux that is a strong source to the atmosphere (Kettle et al., 2001; Ulshöfer et al., 1995; Weiss et al., 1995; Yvon-Lewis and

Published by Copernicus Publications on behalf of the European Geosciences Union. 
Butler, 2001). Terrestrial sources include anthropogenic emissions of $\mathrm{COS}$ and $\mathrm{CS}_{2}$, and to a lesser extent biomass burning, emissions from wetlands and volcanism, and oxidation of $\mathrm{CS}_{2}$ released from anoxic soils (Belviso et al., 1986; Bingemer et al., 1990; Nguyen et al., 1995). The primary sinks of COS are uptake by vegetation, soils, and reaction with OH (Castro and Galloway, 1991; Kuhn et al., 1999; Simmons et al., 1999). The tropospheric lifetime has recently been revised downward from 4.3 years (Chin and Davis, 1995) to about 2.5 y (Montzka et al., 2007), based on an increase in the estimate of the land biosphere sink.

There is an interhemispheric gradient in atmospheric COS of about 3\%, with higher levels in the Southern Hemisphere (SH) (Montzka et al., 2007). This is a consequence of the fact that most of the land sink is located in the Northern Hemisphere $(\mathrm{NH})$, while the oceanic source is largely in the $\mathrm{SH}$. COS levels in the extratropical regions of both hemispheres exhibit large seasonal variations. In the $\mathrm{NH}$, seasonal variability is primarily attributed to seasonal changes in the strength of the vegetative uptake while in the SH it reflects the variability in the oceanic fluxes of COS, $\mathrm{CS}_{2}$, and DMS (Kettle et al., 2002; Montzka et al., 2007).

COS measurements in ice cores and firn air have so far suggested that an atmospheric signal is preserved in the polar ice matrix without major post-depositional artifacts. First measurements of COS in firn air from the Canadian Arctic and Antarctica indicated that COS levels peaked during the 1980 's at 500 ppt (Sturges et al., 2001). Antarctic ice core and firn air measurements were used to construct a 350-year COS atmospheric history (Aydin et al., 2002; Montzka et al., 2004). Those data suggest that atmospheric COS increased from a baseline of 300-350 ppt in the early 19th century to the current levels of 450-500 ppt, coincident with the onset of heavy industrialization. The magnitude of this change implies that roughly $30 \%$ of the COS loading in the troposphere in the industrial era is due to anthropogenic emissions, assuming that other terms in the COS budget remained constant. Measurements on Greenland ice cores are also consistent with COS levels in the 300-350 ppt range during 16501850 (Aydin et al., 2007).

This study presents COS measurements from the SPRESSO ice core drilled near South Pole, Antarctica $\left(89.93^{\circ} \mathrm{S}, 144.39^{\circ} \mathrm{W}\right)$ in 2002 as part of the International Trans-Antarctic Scientific Expedition (ITASE) program (http://www2.umaine.edu/itase/). The SPRESSO core was dry-drilled down to $300 \mathrm{~m}$. The results extend the ice core record of COS to 2200 years before present, providing a first look at COS variability during the late Holocene.

\section{Methods}

Details of the ice core extraction methods and analytical procedures used in this study are given by Aydin et al. (2007). The ice core samples are mechanically shredded in a vacuum chamber for $15 \mathrm{~min}$ at $-50^{\circ} \mathrm{C}$ to liberate the air trapped in the ice. The sample is cryogenically pumped into a $1 / 4 \mathrm{inch}$ stainless-steel tube dipped in liquid helium $(\sim 4 \mathrm{~K})$ and analyzed immediately after recovery. Trace gas quantification was carried out using gas chromatography with mass spectrometric detection. The method entails pre-concentration of the trace gases over glass beads at liquid $\mathrm{N}_{2}$ temperatures $(77 \mathrm{~K})$, chromatographic separation on a non-polar capillary column over a temperature range of $-50^{\circ} \mathrm{C}-120^{\circ} \mathrm{C}$, and analysis with high-resolution mass spectrometry using isotope dilution.

One hundred and twenty four ice core samples were analyzed as part of this project. The data from 10 ice core samples are not presented because the measured CFC-12 levels were higher than $5 \mathrm{ppt}$ (more than twice the detection limit), indicating the presence of modern air in the sample. Eight additional samples were eliminated from the data set because of COS contamination in the shredders or analytical problems with pre- and post-shred blanks that either prevented us from making the measurement or quantifying the analytical blanks.

High purity $\mathrm{N}_{2}$ was passed over the ice core sample before and after the shredding to determine the background COS levels associated with the ice core extraction chambers and vacuum lines. The correction was $(1.3 \pm 1.2) \%$ of the signal on average. COS has a larger molecular mass than $\mathrm{N}_{2}$ and $\mathrm{O}_{2}$, which causes enrichment in the firn air due to gravitational effects (Schwander et al., 1993). Gravitational enrichment at the base of the firn is calculated to be $2 \%$ for the SPRESSO site and this correction was applied to all samples.

The age model used for dating the SPRESSO samples is the same as that used previously for $\mathrm{CH}_{3} \mathrm{Cl}$ and $\mathrm{CH}_{3} \mathrm{Br}$ (Saltzman et al., 2008; Williams et al., 2007). The ice accumulation rate for the SPRESSO core is fairly constant at $8.3 \mathrm{~cm} / \mathrm{y}$ based on visual counting of annual layers down to $207 \mathrm{~m}$ (A. Gow, personal communication, 2007). The accumulation rate is assumed to be constant at this value for the length of the core down to $291 \mathrm{~m}$. No firn sampling was conducted at the SPRESSO site that could be used for determining a precise gas age at firn-ice transition. In a previous South Pole firn study, mean $\mathrm{CO}_{2}$ age at $121 \mathrm{~m}$ depth was reported to be 92 y (Battle et al., 1996), and we assume that this value applies to the SPRESSO core. $\mathrm{A} \mathrm{CO}_{2} / \mathrm{COS}$ molecular diffusivity ratio of 1.234 was calculated using the empirical formula of Wilke et al. (1955). Multiplying the $\mathrm{CO}_{2}$ age of $92 \mathrm{y}$ with this ratio gives a COS gas age of $114 \mathrm{y}$ at a depth of $121 \mathrm{~m}$ and a $\Delta_{\text {age }}$ (ice age - gas age) of $1028 \mathrm{y}$. We subtracted this $\Delta_{\text {age }}$ from the visual stratigraphy-based ice ages to calculate mean COS gas ages for the samples. 


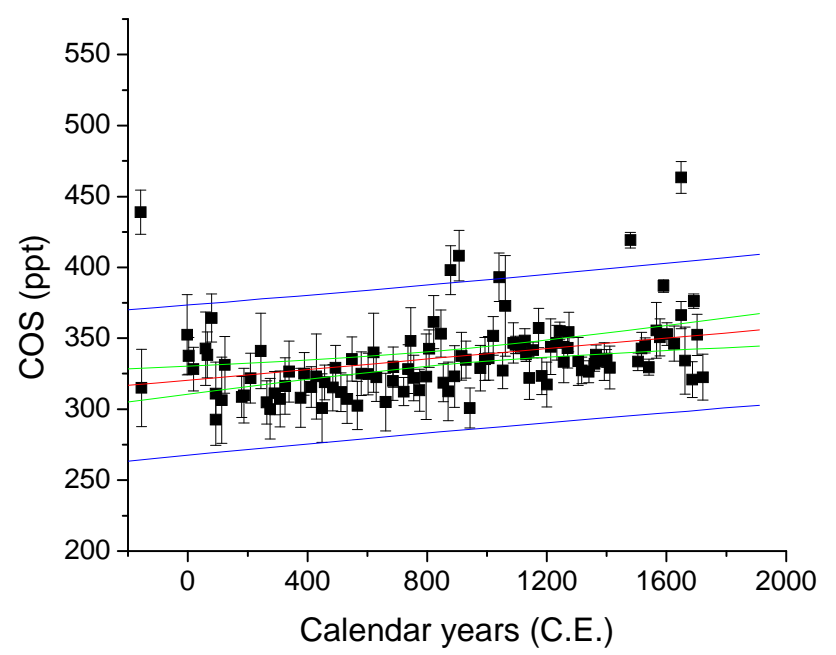

Fig. 1. COS mixing ratios (black squares) measured in air extracted from SPRESSO ice cores. The error bars represent $\pm 1 \sigma$ uncertainty estimate for each data point. The data display a trend (red line) that is statistically significant at $95 \%$. The confidence and prediction bands for the linear fit are bracketed by green and blue lines, respectively.

\section{Results}

The average COS level measured in the SPRESSO ice core is $(336 \pm 28) \mathrm{ppt}( \pm 1 \sigma, n=106)$ with a range of $293-463 \mathrm{ppt}$ (Fig. 1). The error bars $( \pm 1 \sigma)$ shown are on average (5 \pm 2$)$ $\%$ of the reported mixing ratio and represent the cumulative effect of analytical uncertainty and the uncertainty attributed to variability in the blanks. The data exhibit a linear trend of $(1.9 \pm 1.0) \mathrm{ppt}( \pm 2 \sigma)$ increase per $100 \mathrm{y}$.

Six data points lie outside the $95 \%$ prediction band of the linear regression. These six samples also represent the most extreme positive excursions from the neighboring data points. Note that the two outliers from $\sim 900$ C.E. are not adjacent to each other but there is another sample in between (Fig. 1). The samples analyzed in this study are approximately $1 \mathrm{~m}$ apart. At the low snow accumulation rate and temperatures of South Pole, diffusive mixing in the firn air column leads to a broad age distribution of air (Battle et al., 1996). As a result, there is significant age overlap in adjacent samples. It is therefore unlikely that the six outliers represent real variations in the atmospheric composition. Similar outliers were observed in earlier work (Montzka et al., 2004). They may be a result of post-collection contamination or in situ production due to unusual characteristics of the ice from these particular depths. The major ion chemistry of these samples has not yet been measured.

The exclusion of outliers does not significantly change the trend but does improve the statistics. A regression analysis excluding these 6 data points yields a mean of $(331 \pm 18)$ ppt $( \pm 1 \sigma, n=100)$ and a slope of $(1.8 \pm 0.6)$ ppt $( \pm 2 \sigma)$ per $100 \mathrm{y}$. Despite the strong statistical significance of the trend,

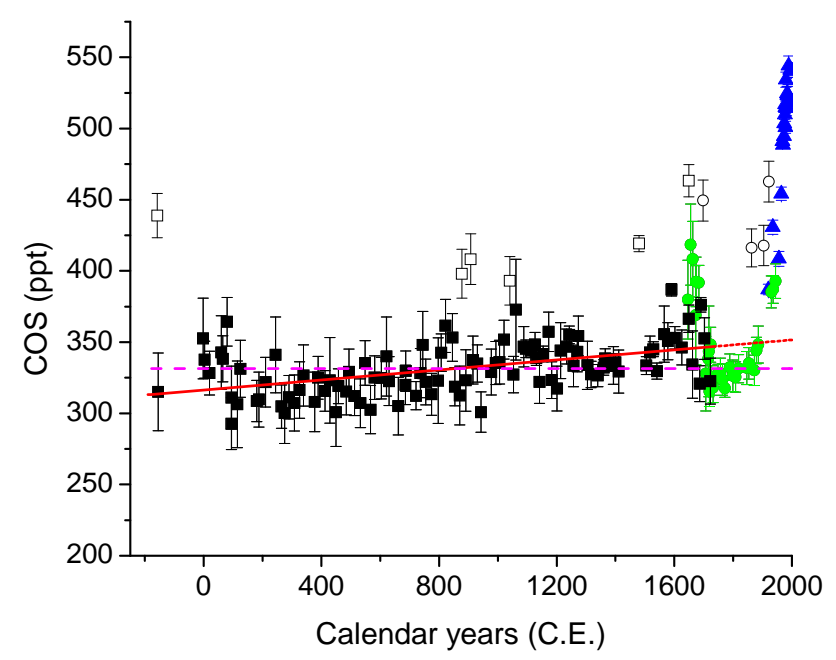

Fig. 2. COS mixing ratios in SPRESSO ice cores (black squares) shown with data from Siple Dome C ice cores (green circles), and South Pole firn air (blue triangles) (Montzka et al., 2004). The open squares and circles represent the outliers in the SPRESSO and Siple Dome $\mathrm{C}$ data sets, respectively. The red line represents the linear trend in SPRESSO data excluding the outliers. It is extended to present day with linear extrapolation (dashed red line). The purple dashed line is the mean of the SPRESSO data excluding the outliers. Error bars represent $\pm 1 \sigma$ uncertainties. The age scales for the ice core data are not actual gas ages but represent a mean over a time period. Because the accumulation rate is higher at Siple Dome than it is at South Pole, any atmospheric gas record is smoothed over a longer time period at South Pole than at Siple Dome. The width of the age distribution at half height is estimated to be $50 \mathrm{y}$ for South Pole and $25 \mathrm{y}$ for Siple Dome based on numerical simulations of the diffusion in firn. A precise assessment of the error associated with the age scales is difficult. We estimate that there can be up to 20-30 years of error in age scales of each data set based on uncertainties involved in layer counting alone. South Pole firn data are plotted against $\mathrm{CO}_{2}$ based gas age estimates. Here, samples from a given depth in the firn are assigned a gas age by comparing the $\mathrm{CO}_{2}$ mixing ratio measured at that depth to the atmospheric history of $\mathrm{CO}_{2}$ based on measurements from Law Dome ice cores and NOAA flask network (Conway et al., 2007; Etheridge et al., 1996). This method is only adequate for developing rough age scales for firn records. A numerical simulation of physical processes in the firn is necessary for more precise atmospheric histories (Schwander et al., 1988).

it does not appear to be a monotonic increase. The mean COS level before 500 C.E. is $(321 \pm 6)$ ppt $( \pm 2$ s.e. $)$ and the mean level after 1100 C.E. is $(342 \pm 6)$ ppt ( \pm 2 s.e.). This difference is significant at the $99 \%$ confidence level and there is no statistically significant trend before 500 C.E. or after 1100 C.E. Thus the overall trend in the SPRESSO data set is due primarily to the rise in COS levels between 500 C.E. and 1100 C.E.

The COS record from the SPRESSO ice core and previously published data from Siple Dome ice and South Pole firn air provide a continuous record of atmospheric COS covering the last two millennia (Fig. 2). The period leading up 


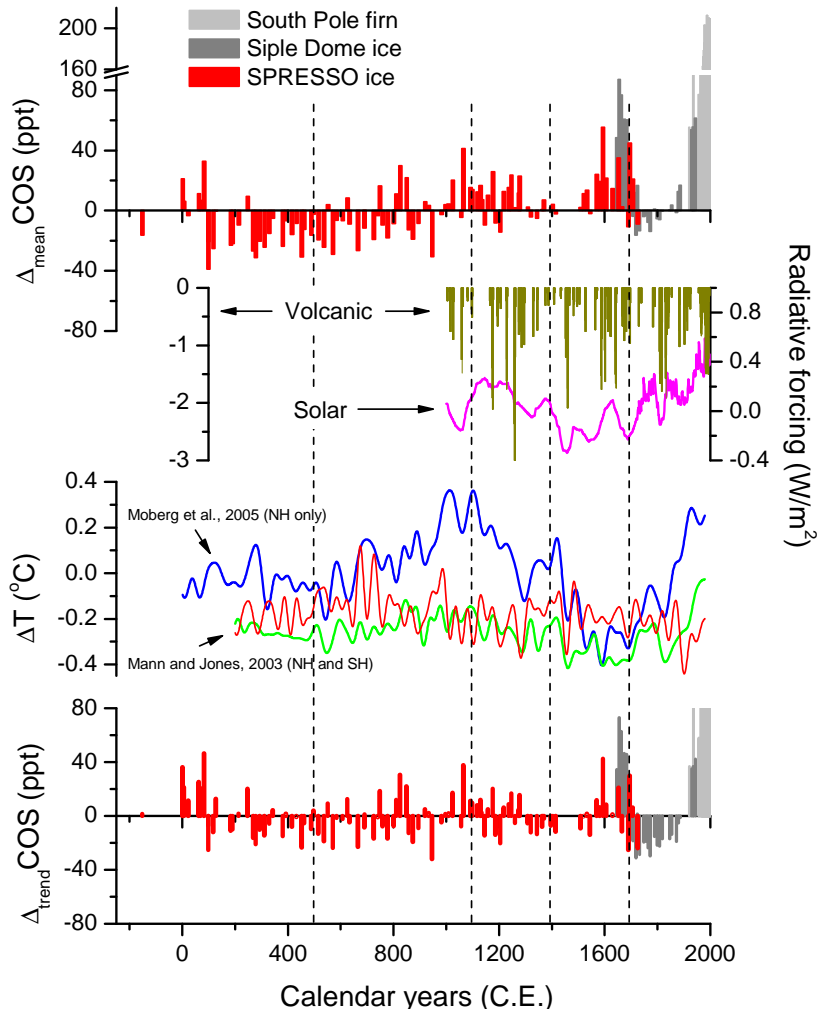

Fig. 3. Top panel - COS anomalies from the mean (331 ppt) for SPRESSO (red), SDM-C (dark gray), and SPO firn (light gray) denoted as $\Delta_{\text {mean }}$ COS. Positive y-axis is truncated between 90 160 ppt because the COS anomalies for the present day are more than twice what they were during the preindustrial period. Middle panel (indented) - Changes in radiative forcing from Crowley (2000) due to volcanic eruptions (5-year smoothed, left y-axis) and solar irradiation (right $\mathrm{y}$-axis). The solar irradiation record is based on ${ }^{10} \mathrm{Be}$ measurements of Bard et al. (2000). Middle Temperature anomalies for the NH from Mann and Jones (2003) (green) and Moberg (2005) (blue), and for the SH from Mann and Jones (2003) (red). All three records are 40-year smoothed. Bottom - COS anomalies from the trend ( $1.8 \mathrm{ppt} / 100 \mathrm{y})$ for SPRESSO (red), SDM-C (dark gray), and SPO firn (light gray) denoted as $\Delta_{\text {trend }} \mathrm{COS}$.

to the industrial era is dominated by a peak between 1600 1700 C.E. COS is relatively low in the first half of the 18 th century and the steep rise that follows during the 19th and 20th centuries is unprecedented. The COS rise during this period is more than $200 \mathrm{ppt}$ in less than 200 years ( $>1$ ppt per year), far exceeding the long term trend of $1.8 \mathrm{ppt}$ COS per $100 \mathrm{y}$, and clearly demonstrating the impact of anthropogenic activities on the atmospheric levels of this gas (Fig. 2).

The intensity, timing, and duration of the COS variability during preindustrial times is more clearly displayed when data are plotted as a deviation from the mean $\left(\Delta_{\text {mean }} \mathrm{COS}\right)$ and deviation from the trend $\left(\Delta_{\text {trend }}\right.$ COS) (Fig. 3, top and bottom panels). Included in Fig. 3 with the COS data are two separate records of $\mathrm{NH}$ temperature changes (middle-

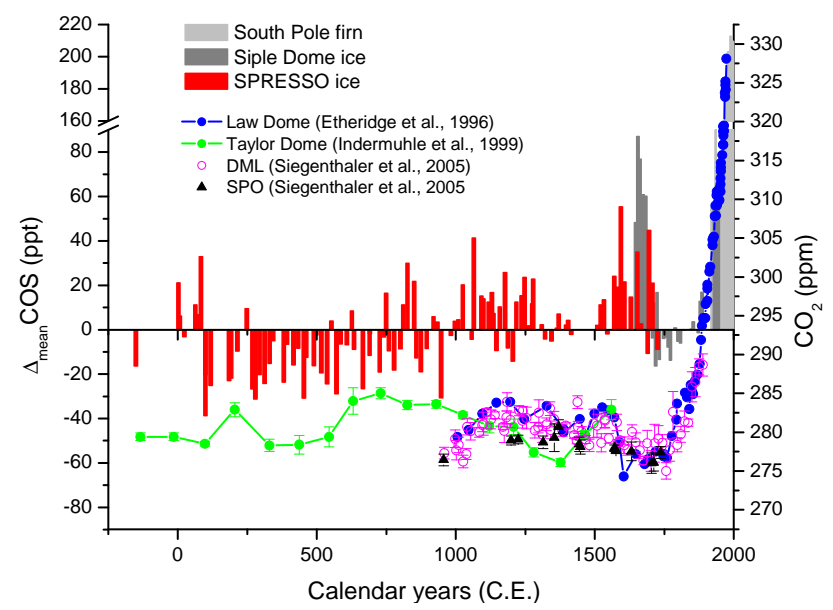

Fig. 4. $\Delta_{\text {mean }}$ COS from Fig. 3 shown against the last 2000 years of $\mathrm{CO}_{2}$ ice core record from Law Dome (Etheridge et al., 1996) (blue), Taylor Dome (Indermühle et al., 1999) (green), DML (Siegenthaler et al., 2005) (magenta), and SPO (Siegenthaler et al., 2005) (black).

bottom panel) (Mann and Jones, 2003; Moberg et al., 2005), a record of SH temperature changes (Mann and Jones, 2003) and estimates of radiative forcing from solar irradiance and volcanism (Crowley, 2000). The lack of discernable trends in the SH temperature record may be due to the lack of highresolution proxy records from that hemisphere (Mann and Jones, 2003). The temperature variability in the NH during the last millennium is largely explainable by variability in solar irradiance, volcanic activity, and atmospheric $\mathrm{CO}_{2}$ levels in models (Crowley, 2000; Gerber et al., 2003). The solar irradiance and volcanic radiative forcing records (Crowley, 2000) shown in Fig. 3 could provide some indication of variations in the photochemical and volcanic COS sources over this time period. A comparison of $\mathrm{COS}$ and $\mathrm{CO}_{2}$ ice core records are presented separately in Fig. 4.

$\mathrm{NH}$ temperatures appear to be steady before 500 C.E. (Fig. 3). During this period, $\Delta_{\text {mean }} \mathrm{COS}$ anomalies are steady around $-20 \mathrm{ppt}$, except for a few of the oldest samples that show positive anomalies. Between 500 C.E. and 1100 C.E., $\Delta_{\text {mean }}$ COS increases from $-20 \mathrm{ppt}$ to $20 \mathrm{ppt}$ while the $\mathrm{NH}$ climate is warming, entering the era generally recognized as the Medieval Climate Anomaly (MCA) (Broecker, 2001; Dahl-Jensen et al., 1998; Grove and Switsur, 1994; Stine, 1994). $\Delta_{\text {trend }}$ COS also displays a change from negative to positive values because the linear trend used to de-trend the data is too small for this period as discussed previously. The apparent 40 ppt change over 600 years implies a COS increase of 6-7 ppt per $100 \mathrm{y}$, or about $2 \%$ per century.

Starting around 1100 C.E., the temperature trend reverses and the NH starts to shift towards the cooler climate of the Little Ice Age (LIA), which peaks during 17th and 18th centuries (Bradley and Jones, 1992; Grove, 1988). COS levels remain steady through 1200 C.E., then appear to go through a 
modest drop and reach a $\Delta_{\text {mean }} \operatorname{COS}$ of $0 \mathrm{ppt}$ and $\Delta_{\text {trend }} \mathrm{COS}$ of about $-15 \mathrm{ppt}$ around 1400 C.E. This minimum is coincident with a short-lived warm period superimposed on the general trend of cooling. The cooling continues for two more centuries between 1400 and 1600 C.E. There is about a 100 year gap in the COS data between 1400 and 1500 C.E., after which COS levels start to increase rapidly. Peak levels of the preindustrial era are reached at $\Delta_{\text {mean }} \operatorname{COS}$ of $60 \mathrm{ppt}$ and $\Delta_{\text {trend }} C O S$ of $40 \mathrm{ppt}$ towards the end of the 1600's despite the persistent cool climate that lasts through 1700 C.E. and into the 18th century. Between 1700 C.E. and 1800 C.E., COS drops rapidly to the lowest levels since 1000 C.E., reaching a negative peak in $\Delta_{\text {trend }} \mathrm{COS}$ of $-30 \mathrm{ppt}$. The rise in COS levels after 1800 C.E. is unparalleled in magnitude during the two thousand years before industrialization. This change is synchronous with the warming trend in climate and the rise in the atmospheric levels of other trace gases like $\mathrm{CO}_{2}$ and $\mathrm{CH}_{4}$ (Etheridge et al., 1998 and 1996).

\section{Possible causes of preindustrial COS variability}

\subsection{Sources}

The biogeochemical cycle of COS is sufficiently complex that there may be numerous causes for preindustrial variability, and perhaps no single factor that controls the relationship between climate and atmospheric COS levels. Oceanic emissions are the largest natural source of COS to the atmosphere. The oceanic flux is a function of: 1) photochemical production of $\mathrm{COS}$ and $\mathrm{CS}_{2}$ from dissolved organic matter, 2) emissions of biogenic $\mathrm{CS}_{2}$ and DMS, and 3) temperaturedependent hydrolysis of COS that irreversibly reduces pCOS levels in the surface ocean. The net result is a positive annual mean flux that peaks in high and mid latitude oceans (Kettle et al., 2002; Kjellström, 1998). Response of the oceanic net flux to changing climate would involve a combination of physical factors affecting photochemical production, hydrolysis and air/sea gas exchange, such as solar irradiance, sea surface temperature, wind speed, and mixed layer depth, and also biological changes that influence the production and cycling of dissolved organic matter and biogenic gases (Kettle et al., 2001). It is unlikely that the processes contributing to the oceanic flux of COS will all respond to a changing climate in the same direction.

There is some evidence that the surface ocean temperatures were warmer during MCA and cooler during LIA (deMenocal et al., 2000; Keigwin, 1996; Lund and Curry, 2006; Newton et al., 2006; Winter et al., 2000), suggesting that in at least parts of the global surface ocean, temperature trends were similar to $\Delta \mathrm{TNH}$ records shown in Fig. 3. The variability of solar irradiance, which may better correlate with just the photochemical production term, appears to diverge from the $\Delta \mathrm{TNH}$ trends over some parts of the 1000 years of overlap (Fig. 3). The drop in solar irradiance following the
MCA is somewhat delayed compared to the cooling in temperatures, and the lowest levels of radiation are experienced in the early 15 th century, long before the minimum temperatures are reached. This is the part of the record when the correlation between the temperature and COS appears to collapse after the period between 500 C.E. and 1100 C.E. during which they rise simultaneously. Based on the complex nature of the relationship between climate and oceanic fluxes, we cannot rule out the possibility that the response of the oceanic fluxes to changes in climate forcing contributed heavily to the COS variability through the entirety of the preindustrial era.

Volcanic emissions are one of the natural sources of COS and constitute roughly $10 \%$ of the natural sources of COS cited in the current budgets (based on maximum emission estimates of $90 \mathrm{Gg}$ of $\mathrm{S}$ from volcanoes and $873 \mathrm{Gg}$ of $\mathrm{S}$ total from non-industrial sources) (Belviso et al., 1986; Chin and Davis, 1993; Kettle et al., 2002). The magnitude of the total COS flux due to volcanic activity is highly uncertain (Belviso et al., 1986; Cadle, 1980; Khalil and Rasmussen, 1984). It is estimated that about $50 \%$ of COS emissions occurs during eruptions and most of the remaining 50\% is attributed to post-eruptive emissions, with emissions during quiescent periods constituting less than $1 \%$ (Belviso et al., 1986). In addition to direct volcanic emissions of COS, volcanism can also affect the atmospheric COS levels through indirect mechanisms that involve changes in oceanic and terrestrial ecosystem fluxes as a response to climate cooling induced by eruptions. It is not clear whether such indirect effects would lead to an increase or decrease in COS emissions.

Variability in eruptive volcanic activity over the past millennium can be qualitatively inferred from a reconstruction of stratospheric aerosol radiative forcing (Crowley, 2000), which in turn is based primarily on the Crete (Crowley et al., 1993; Hammer et al., 1980) and GISP2 (Zielinski, 1995) Greenland ice core sulfate records (Fig. 3). This composite record is more heavily weighted towards northern hemispheric eruptions although it accounts for major eruptions in the Southern Hemisphere that occurred in or near the tropics.

The first intense period of volcanism in the record occurs around 1200-1300 C.E., possibly contributing to start of the northern hemispheric cooling trend at the end of the MCA (Fig. 3). During this period, COS levels remain steady despite the cooling trend in temperatures. There is a brief period of intensified volcanic activity in the 1400's, overlapping with the gap in the COS data. A longer period of high volcanic activity occurs around 1600-1700 C.E. This coincides with the height of the LIA and elevated COS levels. The 18th century minimum in COS coincides with a quiescent period in volcanic activity and the start of the COS rise during the 19th century is again marked by intensified volcanic activity. The apparent qualitative agreement in the timing of the patterns of variability in COS and volcanism suggests that volcanic COS emissions may have had a measurable impact on the preindustrial atmosphere. Further studies are needed to better quantify the present day volcanic emissions of COS. 
Relatively little is known about the paleo-variability of the other COS sources. It is possible that the changes in emissions from biomass burning, wetlands, and anoxic soils also contributed to the pre-industrial variability of COS. It has been suggested that biomass burning emissions were reduced during the period between the MCA and LIA (Ferretti et al., 2005; Savarino and Legrand, 1998; Swetnam, 1993; Verschuren et al., 2000). Modern budget estimates suggest that the biomass burning comprises less than $10 \%$ of the total non-industrial COS emissions (Kettle et al., 2002; Watts, 2000). Emissions from biomass burning would have to undergo changes on the order of $100 \%$ or larger to have a measurable impact on the ice core COS records.

\subsection{Sinks}

Preindustrial COS variability can also be driven by changes in uptake by terrestrial vegetation. This sink currently accounts for up to $80 \%$ of the total atmospheric losses (Montzka et al., 2007; Sandoval-Soto et al., 2005) so even modest changes in this term can cause variability of the order observed in the ice core record. The photosynthetic activity of terrestrial plants should vary with changing climate (Braswell, et al., 1997; Cao and Woodward, 1998; McMillan et al., 2008; Melillo et al., 1993), and possibly also as a response to dramatic changes in global land cover during the last few centuries (Houghton, 2003; Ramankutty and Foley, 1999).

COS is taken up by plants during photosynthesis and converted to $\mathrm{H}_{2} \mathrm{~S}$ via hydrolysis catalyzed by the carbonic anhydrase enzyme (Notni et al., 2007; Protoschill-Krebs et al., 1996; Protoschill-Krebs and Kesselmeier, 1992). Carbonic anhydrase also catalyzes the conversions between $\mathrm{CO}_{2}$ and $\mathrm{HCO}_{3}^{-}$in plants and it has been shown that most of the $\mathrm{CO}_{2}$ taken up by leaf stomata undergoes hydrolysis (Gillon and Yakir, 2001). However, in $C_{3}$ plants that make up most of the terrestrial vegetation, the catalytic activity of carbonic anhydrase contributes little to the overall carbon fixation by photosynthesis (Badger and Price, 1994; Cowan, 1986).

Based on the commonalities in the metabolism of COS and $\mathrm{CO}_{2}$ in plants, it has been suggested that the uptake of COS from the atmosphere can provide insight into carbon assimilation by terrestrial vegetation (Kesselmeier et al., 1997; Kettle et al., 2002; Montzka et al., 2007). While both COS and $\mathrm{CO}_{2}$ are removed from the atmosphere during photosynthesis, only $\mathrm{CO}_{2}$ is returned to the atmosphere via respiration. The amplitude of the seasonal drop in COS mixing ratios during the spring-summer growing season over Northern Hemisphere continental land masses can be 5-8 times that of $\mathrm{CO}_{2}$ relative to mean levels of each gas (Montzka et al., 2007; Xu et al., 2002). While this empirical modern ratio cannot be assumed to hold for all ecosystems and differing climates, it does suggest that changes in global photosynthetic activity could cause synchronous changes in the paleorecords of both $\mathrm{COS}$ and $\mathrm{CO}_{2}$.
Figure 4 is a comparison of the $\mathrm{COS}$ and $\mathrm{CO}_{2}$ ice core records from Antarctic sites. $\mathrm{CO}_{2}$ data are from Law Dome (Etheridge et al., 1996), Taylor Dome (Indermühle et al., 1999), Dronning Maud Land (Siegenthaler et al., 2005), and South Pole (Siegenthaler et al., 2005). The temporal resolution of $\mathrm{CO}_{2}$ data from the earlier 1000 years of the comparison period is poor relative to that of the COS record but there is not a clear trend in $\mathrm{CO}_{2}$ between 500 C.E. and 1700 C.E. when $\mathrm{COS}$ anomalies change from negative to positive values. There appears to be a drop from $\sim 285 \mathrm{ppm}$ (Taylor Dome, parts per million as $\mathrm{mol} / \mathrm{mol}$ ) around 700 C.E. to a minimum of $\sim 277 \mathrm{ppm}$ (Law Dome, Dronning Maud Land, and South Pole) at the height of the LIA. It is difficult to assess the significance of this negative trend, however, because the Taylor Dome record deviates from the others by more than $5 \mathrm{ppm}$ around 900 C.E. There is also no sharp rise in $\mathrm{CO}_{2}$ levels in the beginning of the LIA. There may instead be a divergence between the trends of $\mathrm{COS}$ and $\mathrm{CO}_{2}$ mean levels during the last 1000 years. It is not likely that the COS spike during 1600-1700 C.E. is linked to drastic changes in the vegetative sink. Overall, there is no evidence of correlation between the atmospheric levels of these trace gases over the length of these records except during 19th and 20th centuries when emissions from fossil fuel burning started to dominate the variability of $\mathrm{CO}_{2}$ in the atmosphere (Etheridge et al., 1996; Francey et al., 1999).

The other significant sinks of COS are oxidation by atmospheric $\mathrm{OH}$ and uptake by oxic soils. Little is known about the preindustrial variability of these terms. Assuming that vegetative uptake comprises $80 \%$ of the COS total sinks, changes in these minor sink terms would have to be larger than $50 \%$ to cause COS fluctuations on the order of $5-10 \%$.

\section{Conclusions}

The ice core record obtained from the SPRESSO core is in general agreement with the prior atmospheric history of COS developed from Siple Dome ice cores. The physical environmental parameters at South Pole and Siple Dome are quite different, the latter location being $\sim 25^{\circ} \mathrm{C}$ warmer and receiving about $20-40 \%$ more snow accumulation on a yearly average basis. The consistency between the results strongly suggest that in situ production or loss mechanisms do not dominate the COS mixing ratios measured in air extracted from these Antarctic ice cores. Given the large difference in mean annual temperatures of these two sites, the potential exists that a genuine paleo-archive of atmospheric COS is preserved in most Antarctic glaciers. Sites that experience warmer temperatures may still present problems associated with post-depositional artifacts related to temperature dependent hydrolysis of COS in liquid-like layers on the ice surface (Assonov et al., 2005). Similarly, the stability of COS in ice cores over longer time-scales and under climatic conditions different than those during the late Holocene is yet 
to be tested. Long records from multiple sites are needed to explore whether ice cores can be used for obtaining consistent atmospheric records of COS over glacial-interglacial time-scales.

The SPRESSO results display natural COS variability of $10-15 \%$ around a mean of $330 \mathrm{ppt}$ over the last two millennia. Over the entire length of the ice core COS record, the mixing ratios do not exceed $400 \mathrm{ppt}$. The rate at which mean COS levels changed during the 20th century and the magnitude of this change are strong indicators that most of this rise resulted from anthropogenic activities. Thus the current results do not challenge prior assessments of the anthropogenic impact on the COS burden in the atmosphere. There is evidence of variability in the natural COS fluxes, however, and it is unlikely that they were in a steady-state during the 19th and 20th centuries when climate warming was already underway coming out of the LIA.

The most persistent long term change evident in the data is a $\sim 40$ ppt increase that happened between 500 C.E. and 1100 C.E. This event coincides in time with the overall warming trend in the $\mathrm{NH}$ climate heading into the MCA. It is also evident that COS levels during the preindustrial era peaked around the height of the LIA when the NH climate was at its coldest during the late Holocene. Clearly, the current COS record does not co-vary uniformly with the proxy temperature records of the last 2000 years. It has been suggested that the LIA cold anomaly was at least in part due to the effects of intense volcanic activity on the global radiative budget. It is possible that the COS peak during LIA is also linked to intense volcanism during that era, although there is considerable uncertainty about both the COS emissions from volcanism and the extent to which the ice core sulfate record can be used as a proxy for gaseous volcanic emissions. Understanding the causes of the variations requires reliable proxies for individual source and sink terms of the COS budget rather than a generalized indicator of hemispheric climate shifts. Given the importance of vegetative uptake during photosynthesis as a sink term in the COS budget, it is somewhat surprising that there is no apparent correlation between COS and $\mathrm{CO}_{2}$ ice core records over the study period.

Acknowledgements. This work was supported by the National Science Foundation's Office of Polar Programs (OPP-0338359, OPP-0440602) and the Comer Science and Education Foundation. We would like to thank Tony Gow and Debra Meese for layer counting data, and the National Ice Core Laboratory for assistance with ice core samples. We also would like to thank Andrew McMillan for helpful comments on the manuscript.

Edited by: J. Kaiser

\section{References}

Assonov, S. S., Brenninkmeijer, C. A. M., and Jockel, P.: The ${ }^{18} \mathrm{O}$ isotope exchange rate between firn air $\mathrm{CO}_{2}$ and the firn air matrix at three Antarctic sites, J. Geophys. Res., 110, D18310, doi:10.1029/2005JD005769, 2005.

Aydin, M., DeBruyn, W. J., and Saltzman, E. S.: Preindustrial atmospheric carbonyl sulfide (OCS) from an Antarctic ice core, Geophys. Res. Lett., 2, 1359, doi:10.1029/2002GL014796, 2002.

Aydin, M., Williams, M. B., and Saltzman, E. S.: Feasibility of reconstructing paleoatmospheric records of selected alkanes, methyl halides, and sulfur gases from Greenland ice cores, J. Geophys. Res., 112, D07312, doi:10.1029/2006JD008027, 2007.

Badger, M. R. and Price, G. D.: The role of carbonic anhydrase in photosynthesis, Annu. Rev. Plant Physiol. Plant Mol. Biol., 45, 369-392, 1994.

Bandy, A. R., Thornton, D. C., Scott, D. L., Lalevic, M., Lewin, E. E., and Driedger III, A. R.: A time series for carbonyl sulfide in the Northern Hemisphere, J. Atmos. Chem., 14, 527-534, 1992.

Bard, E., Raisbeck, G., Yiou, F., and Jouzel, J.: Solar irradiance during the last 1200 years based on cosmogenic nuclides, Tellus, 52B, 985-992, 2000.

Barkley, M. P., Palmer, P. I., Boone, C. D., Bernath, P. F., and Suntharalingam, P.: Global distributions of carbonyl sulfide in the upper troposphere and stratosphere, Geophys. Res. Lett., 35, L14810, doi:10.1029/2008GK034270, 2008.

Barnes, I., Becker, K. H., and Petroescu, I.: The tropospheric oxidation of DMS: A new source of OCS, Geophys. Res. Lett., 21, 2389-2392, 1994.

Battle, M., Bender, M., Sowers, T., Tans, P. P., Butler, J. H., Elkins, J. W., Ellis, J. T., Conway, T., Zhang, N., Lang, P., and Clarke, A. D.: Atmospheric gas concentrations over the past century measured in air from firn at the South Pole, Nature, 383(6597), 231235, 1996.

Belviso, S., Nguyen, B. C., and Allard, P.: Estimate of carbonyl sulfide volcanic source strength deduced from $\mathrm{OCS} / \mathrm{CO}_{2}$ ratios in volcanic gases, Geophys. Res. Lett., 3, 133-136, 1986.

Bingemer, H. G., Buergermeister, S., Zimmermann, R. L., and Georgii, H. W.: Atmospheric OCS: evidence for a contribution of anthropogenic sources?, J. Geophys. Res., 95, 20617-20622, 1990.

Bradley, R. S. and Jones, P. D.: Climate since A.D. 1500, 665 pp., Routledge, Chapman and Hall, New York, 1992.

Brasswell, B. H., Schimel, D. S., Linder, E., and Moore III, B.: The response of global terrestrial ecosystems to interannual temperature variability, Science, 278, 870-972, 1997.

Broecker, W. S.: Paleoclimate - Was the medieval warm period global?, Science, 291(5508), 1497-1499, 2001.

Cadle, R. D.: A comparison of volcanic and other fluxes of atmospheric trace gas constituents, Rev. Geophys. Space Phys., 18, 746-752, 1980.

Cao, M. and Woodward, F. I.: Dynamic responses of terrestrial ecosystem carbon cycling to global climate change, Nature, 393 , 249-252, 1998.

Castro, M. S. and Galloway, J. N.: A comparison of sulfur-free and ambient air enclosure techniques for measuring the exchange of reduced sulfur gases between soils and the atmosphere, J. Geophys. Res., 96, 15427-15437, 1991.

Chin, M.: An atmospheric study of carbonyl sulfide and carbondisulfide and their relationship to stratospheric background 
sulfur aerosol, Ph.D. thesis, Ga. Inst. of Technol., Atlanta, 1991.

Chin, M. and Davis, D. D.: Global sources and sinks of OCS and $\mathrm{CS}_{2}$ and their distributions, Global Biogeochem. Cycl., 7, 321337, 1993.

Chin, M. and Davis, D. D.: A reanalysis of carbonyl sulfide as a source of stratospheric background sulfur aerosol, J. Geophys. Res., 100, 8993-9006, 1995.

Conway, T. J., Lang, P. M., and Masarie, K. A.: Atmospheric Carbon Dioxide Dry Air Mole Fractions from the NOAA ESRL Carbon Cycle Cooperative Global Air Sampling Network, 19682006, Version: 2007-09-19, online: ftp://ftp.cmdl.noaa.gov/ccg/ co2/flask/event/, 2007.

Cowan, I. R.: Economics of carbon fixation in higher plants, On the economy of plant form and function, edited by: Givinish, T. J., London, Cambridge Univ. Pres., 130-170, 1986.

Crowley, T. J.: Causes of climate change over the past 1000 years, Science, 289, 270-277, 2000.

Crowley, T. J., Criste, T. A., and Smith, N. R.: Reassessment of Crete (Greenland) ice core acidity/volcanism link to climate change, Geophys. Res. Lett., 20, 209-212, 1993.

Crutzen, P.: Possible importance of CSO for sulfate layer of stratosphere, Geophys. Res. Lett., 3, 73-76, 1976.

Dahl-Jensen, D., Mosegaard, K., Gundestrup, N., Clow, G. D., Johnsen, S. J., Hansen, A. W., and Balling, N.: Past Temperatures Directly from the Greenland Ice Sheet, Science, 282(5387), 268-271, 1998.

deMenocal, P., Ortiz, J., Guilderson, T., and Sarnthein, M.: Coherent high- and low-latitude climate variability during the Holocene warm period, Science, 288, 2198-2202, 2000.

Etheridge, D. M., Steele, L. P., Langenfelds, R. L., Francey, R. J., Barnola, J.-M., and Morgan, V. I.: Natural and anthropogenic changes in atmospheric $\mathrm{CO}_{2}$ over the last 1000 years from air in Antarctic ice and firn, J. Geophys. Res., 101(D2), 4115-4128, 1996.

Etheridge, D. M., Steele, L. P., Francey, R. J., and Langenfelds, R. L.: Atmospheric methane between 1000 A.D. and present: Evidence of anthropogenic emissions and climatic variability, J. Geophys. Res., 103, 15979-15993, 1998.

Ferretti, D. F., Miller, J. B., White, J. W. C., Etheridge, D. M., Lassey, K. R., Lowe, D. C., Meure, C. M. M., Dreier, M. F., Trudinger, C. M., van Ommen, T. D., and Langenfelds, R. L.: Unexpected changes to the global methane budget over the past 2000 years, Science, 309(5741), 1714-1717, 2005.

Francey, R. J., Allison, C. E., Etheridge, D. M., Trudinger, C. M., Enting, I. G., Leuenberger, M., Langenfelds, R. L., Michel, E., and Steele, L. P.: A 1000-year high precision record of ${ }^{13} \mathrm{C}$ in atmospheric $\mathrm{CO}_{2}$, Tellus, 51B, 170-193, 1999.

Gerber, S., Joos, F., Brugger, P., Stocker, T. F., Mann, M. E., Sitch, S., and Scholze, M.: Constraining temperature variations over the last millennium by comparing simulated and observed atmospheric $\mathrm{CO}_{2}$, Clim. Dynam., 20, 281-299, doi:10.1007/s00382002-0270-8, 2003.

Gillon, J. and Yakir, D.: Influence of carbonic anhydrase activity in terrestrial vegetation on the ${ }^{18} \mathrm{O}$ content of atmospheric $\mathrm{CO}_{2}$, Science, 291, 2584-2587, 2001.

Golombek, A. and Prinn, R. G.: A global three-dimensional model of the stratospheric sulfuric acid layer, J. Atmos. Chem., 16, 179199, 1993.

Griffith, D. W. T., Jones, N. B., and Matthews, W. A.: Interhemi- spheric ratios and annual cycle of carbonyl sulfide (OCS) total column from ground-based solar FTIR spectra, J. Geophys. Res., 103, 8447-8454, 1998.

Grove, J. M.: Little Ice Ages, Vol. 1, 1-402, Routledge, New York, 1988.

Grove, J. M. and Switsur, R.: Glacial Geological Evidence for the Medieval Warm Period, Climatic Change, 26(2-3), 143-169, 1994.

Hammer, C. U., Clausen, H. B., and Dansgaard, W.: Greenland ice sheet evidence of post-glacial volcanism and its climatic impact, Nature, 288, 230-235, 1980.

Hofmann, D. J.: Increase in the stratospheric background sulfuric acid aerosol mass in the past 10 years, Science, 248, 996-1000, 1990.

Houghton, R. A.: Revised estimates of the annual net flux of carbon to the atmosphere from changes in land use and land management 1850-2000, Tellus, 55B, 378-390, 2003.

Indermühle, A., Stocker, T. F., Joos, F., Fischer, H., Smith, H. J., Wahlen, M., Deck, B., Mastroianni, D., Tschumi, J., Blunier, T., Meyer, R., and Stauffer, B.: Holocene carbon-cycle dynamics based on $\mathrm{CO}_{2}$ trapped in ice at Taylor Dome, Antarctica, Nature, 398, 121-126, 1999.

Keigwin, L. D.: The Little Ice Age and Medieval warm period in the Sargasso Sea, Science, 274(5292), 1504-1508, 1996.

Kesselmeier, J., Schröder, P., and Erisman, J. W.: Exchange of sulfur gases between the biosphere and the atmosphere, Transport and Chemical Transformation of Pollutants in the Troposphere, Vol. 4, Biosphere-Atmosphere Exchange of Pollutants and Trace Substances, edited by: Slanina S., 167-198, Chapt. 4, SpringerVerlag, New York, 1997.

Kettle, A. J., Rhee, T. S., von Hobe M., Poulton, A., Aiken, J., and Andreae, M. O.: Assessing the flux of volatile sulfur gases from the ocean to the atmosphere, J. Geophys. Res., 106, 1219312209, 2001.

Kettle, A. J., Kuhn, U., von Hobe, M., Kesselmeier, J., and Andreae, M. O.: Global budget of atmospheric carbonyl sulfide: Temporal and spatial variations of the dominant sources and sinks, J. Geophys. Res., 107(D22), 4658, doi:10.1029/2002JD002187, 2002.

Khalil, M. A. K. and Rasmussen, R. A.: Global sources, lifetimes, and mass balances of carbonyl sulfide (OCS) and carbon disulfide $\left(\mathrm{CS}_{2}\right)$ in the earth's atmosphere, Atmos. Environ., 18, 18051813, 1984.

Kjellström, E.: A three-dimensional global model study of carbonyl sulfide in the troposphere and lower stratosphere, J. Atmos. Chem., 29, 151-177, 1998.

Kuhn, U., Ammann, C., Wolf, A., Meixner, F. X., Andreae, M. O., and Kesselmeier, J.: Carbonyl sulfide exchange on an ecosystem scale: soil represents a dominant sink for atmospheric COS, Atmos. Environ., 33, 995-1008, 1999.

Leung, F.-Y. T., Colussi, A. J., and Hoffmann, M.: Isotopic fractionation of carbonyl sulfide in the atmosphere: Implications for the source of background stratospheric sulfate aerosol, Geophys. Res. Lett., 29(10), 1474, doi:10.1029/2001GL013955, 2002.

Lund, D. C. and Curry, W.: Florida Current surface temperature and salinity variability during the last millennium, Paleoceanography, 21(2), PA2009, doi:10.1029/2005PA001218, 2006.

Mahieu, E., Rinsland, C. P., Zander, R., Duchatelet, P., and Servais, C.: Tropospheric and stratospheric carbonyl sulfide (OCS): Long-term trends and seasonal cycles above the Jungfru- 
ajoch station, Proceedings of the Sixth European Symposium on Stratospheric Ozone, 309-312, Goteborg, Sweden, 2-6 September 2002, 2003.

Mann, M. E. and Jones, P. D.: Global surface temperatures over the past two millennia, Geophys. Res. Lett., 30(15), 1820, doi:10.1029/2003GL017814, 2003.

McMillan, A. M. S., Winston, G. C., and Goulden, M. L.: Age dependent response of boreal forests to temperature and rainfall variability, Global Change Biol., 14, 1-13, doi:10.1111/j.13652486.2008.01614.x, 2008.

Melillo, J. M., McGuire, A. D., Kicklighter, D.W., Moore III, B., Vorosmarty, C. J., and Schloss, A. L.: Global climate change and terrestrial net primary production, Nature, 363, 234-240, 1993.

Mihalopoulos, N., Putaud, J. P., Nguyen, B. C., and Belviso, S.: Annual variation of atmospheric carbonyl sulfide in the marine atmosphere in the southern Indian Ocean, J. Atmos. Chem., 13, 73-82, 1991.

Moberg, A., Sonechkin, D. M., Holmgren, K., Datsenko, N. M., and Karlen, W.: Highly variable Northern Hemisphere temperatures reconstructed from low- and high-resolution proxy data, Nature, 433(7026), 613-617, 2005.

Montzka, S. A., Aydin, M., Battle, M., Butler, J. H., Saltzman, E. S., Hall, B. D., Clarke, A. D., Mondeel, D., and Elkins, J. W.: A 350-year atmospheric history for carbonyl sulfide inferred from Antarctic firn air and air trapped in ice, J. Geophys. Res., 109, D22302, doi:10.1029/2004JD004686, 2004.

Montzka, S. A., Calvert, P., Hall, B. D., Elkins, J. W., Conway, T. J., Tans, P. P., and Sweeney, C.: On the global distribution, seasonality, and budget of atmospheric carbonyl sulfide (COS) and some similarities to $\mathrm{CO}_{2}$, J. Geophys. Res., 111, D09302, doi:10.1029/2006JD007665, 2007.

Myhre, G., Berglen, T. F., Myhre, C. E. L., and Isaksen, I. S. A.: The radiative effect of the anthropogenic influence on the stratospheric sulfate aerosol layer, Tellus, 56B, 294-299, 2004.

Newton, A., Thunell, R., and Stott, L.: Climate and hydrographic variability in the Indo-Pacific Warm Pool during the last millennium, Geophys. Res. Lett., 33(19), L19710, doi:10.1029/2006GL027234, 2006.

Nguyen, B. C., Mihalopoulos, N., Putard, J. P., and Bonsang, B.: OCS emissions from biomass burning in the tropics, J. Atmos. Chem., 22, 55-65, 1995.

Notholt, J., Kuang, Z., Rinsland, C. P., Toon, G. C., Rex, M., Jones, N., Albrecht, T., Deckelmann, H., Krieg, J., Weinzierl, C., Bingemer, H., Weller, R., and Schrems, O.: Enhanced upper tropical tropospheric COS: Impact on the stratospheric aerosol layer, Science, 300, 307-310, 2003.

Notni, J., Schenk, S., Protoschill-Krebs, G., Kesselmeier, J., and Anders, E.: The missing link in COS metabolism: A model study on the reactivation of carbonic anhydrase from its hydrosulfide analogue, Chem. Bio . Chem., 8, 530-536, 2007.

Patroescu, I. V., Barnes, I., Becker, K. H., and Mihalopoulos, N.: FT-IR product study of the $\mathrm{OH}$-initiated oxidation of DMS in the presence of $\mathrm{NO}_{\mathrm{X}}$, Atmos. Environ., 33, 25-35, 1999.

Pitari, G., Mancini, E., Rizi, V., and Shindell, D. T.: Impact of future climate and emission changes on stratospheric aerosols and ozone, J. Atmos. Sci., 59, 414-440, 2002.

Protoschill-Krebs, G. and Kesselmeier, J.: Enzymatic pathways for the metabolization of carbonyl sulphide (COS) by higher plants, Bot. Acta, 105, 206-212, 1992.
Protoschill-Krebs, G., Wilhelm, C., and Kesselmeier, J.: Consumption of carbonyl sulfide (COS) by higher plant carbonic anhydrase (CA), Atmos. Environ., 30, 3151-3156, 1996.

Ramankutty, N. and Foley, J. A.: Estimating historical changes in global land cover: Croplands from 1700 to 1992, Global Biogeochem. Cy., 13, 997-1027, 1999.

Rinsland, C. P., Goldman, A., Mahieu, E., Zander, R., Notholt, J., Jones, N. B., Griffith, D. W. T., Stephen, T. M., and Liou, L. S.: Ground-based infrared spectroscopic measurements of carbonyl sulfide: Free tropospheric trends from a 24-year time series of solar absorption measurements, J. Geophys. Res., 107(D22), 4657, doi:10.1029/2002JD002522, 2002.

Saltzman, E. S., Aydin, M., Tatum, C., and Williams, M. B.: 2000-year record of atmospheric methyl bromide from a South Pole ice core, J. Geophys. Res., 113, D05304, doi:10.1029/2007JD008919, 2008.

Sandoval-Soto, L., Stanimirov, M., von Hobe, M., Schmitt, V., Valdes, J., Wild, A., and Kesselmeier, J.: Global uptake of carbonyl sulfide (COS) by terrestrial vegetation: Estimates corrected by deposition velocities normalized to the uptake of carbon dioxide $\left(\mathrm{CO}_{2}\right)$, Biogeosciences, 2, 125-132, 2005, http://www.biogeosciences.net/2/125/2005/.

Savarino, J. and Legrand, M.: High northern latitude forest fires and vegetation emissions over the last millennium inferred from the chemistry of a central Greenland ice core, J. Geophys. Res., 103(D7), 8267-8279, 1998.

Schneider, M.: Continuous observations of atmospheric trace gases by ground-based FTIR spectroscopy at Izaña Observatory, Tenerife Island, Dissertation, Universität Karlsruhe, Karlsruhe, Germany, 2002.

Schwander, J., Stauffer, B., and Sigg, A.: Air mixing in firn and the age of the air at pore close-off, Ann. Glaciol., 10, 141-145, 1988

Schwander, J., Barnola, J.-M., Andrie, C., Leuenberger, M., Ludin, A., Raynaud, D., and Stauffer, B.: The age of the air in the firn and ice at Summit, Greenland, J. Geophys. Res., 98, 2831-2838, 1993.

Sedlacek, W. A., Mroz, E. J., Lazrus, A. L., and Gandrud, B. W.: A decade of stratospheric sulfate measurements compared with observations of volcanic eruptions, J. Geophys. Res., 88, 37413776, 1983.

Siegenthaler, U., Monnin, E., Kawamura, K., Spahni, R., Schwander, J., Stauffer, B., Stocker, T. F., Barnola, J.-M., and Fischer, H.: Supporting evidence from the EPICA Cronning Maud Land ice core for atmospheric $\mathrm{CO}_{2}$ changes during the past millennium, Tellus, 57B, 51-57, 2005.

Simmons, J. S., Klemedtsson, L., Hultberg, H., and Hines, M.: Consumption of atmospheric carbonyl sulfide by coniferous boreal forest soils, J. Geophys. Res., 104, 11569-11576, 1999.

Stine, S.: Extreme and persistent drought in California and Patagonia during medieval time, Nature, 369(6481), 546-549, 1994.

Sturges, W. T., Penkett, S. A., Barnola, J.-M., Chappellaz, J., Atlas, E., and Stroud, V.: A long-term record of carbonyl sulfide (COS) in two hemispheres from firn air measurements, Geophys. Res. Lett., 28, 4095-4098, 2001.

Swetnam, T. W.: Fire history and climate-change in giant sequoia groves, Science, 262(5135), 885-889, 1993.

Thomason, L. W., Kent, G. S., Trepte, C. R., and Poole, L. R.: A comparison of the stratospheric aerosol background periods of 1979 and 1989-1991, J. Geophys. Res., 102, 3611-3616, 1997. 
Turco, R. P., Whitten, R. C., Toon, O. B., Pollack, J. B., and Hamill, P.: OCS, stratospheric aerosols and climate, Nature, 283-286, 1980.

Ulshöfer, V. S., Uher, G., and Andreae, M. O.: Evidence for a winter sink of atmospheric carbonyl sulfide in the northeast Atlantic Ocean, Geophys. Res. Lett., 22, 2601-2604, 1995.

Verschuren, D., Laird, K. R., and Cumming, B. F.: Rainfall and drought in equatorial east Africa during the past 1100 years, Nature, 403(6768), 410-414, 2000.

Watts, S. F.: The mass budgets of carbonyl sulfide, dimethyl sulfide, carbon disulfide and hydrogen sulfide, Atmos. Environ., 34, 761$779,2000$.

Weisenstein, D. K., Yue, G. K., Ko, M. K. W., Sze, N. D., Rodriguez, J. M., and Scott, C. J.: A two-dimensional model of sulfur species and aerosols, J. Geophys. Res., 102, 13019-13035, 1997.

Weisenstein, D. K. and Bekki, S., Mills, M. Pitari, G., Timmreck, C., et al.: Modeling of Stratospheric Aerosols, Stratosperic Processes and Their Role in Climate (SPARC), report 4, edited by: Thomason, L. and Peter, T., World Clim. Res. Programme, Geneva, Switzerland, 2006.

Weiss, P. S., Johnson, J. E., Gammon, R. H., and Bates, T. S.: Reevaluation of the open ocean source of carbonyl sulfide to the atmosphere, J. Geophys. Res., 100, 23083-23092, 1995.
Wilke, C. R. and Lee, C. Y.: Estimation of diffusion coefficients for gases and vapours, Ind. Eng. Chem., 47, 1253-1257, 1955.

Williams, M. B., Aydin, M., Tatum, C., and Saltzman, E. S.: A 2000 year atmospheric history of methyl chloride from a South Pole ice core: Evidence for climate-controlled variability, Geophys. Res. Lett., 34, L07811, doi:10.1029/2006GL029142, 2007.

Winter, A., Ishioroshi, H., Watanabe, T., Oba, T., and Christy, J.: Caribbean sea surface temperatures: two-to-three degrees cooler than present during the Little Ice Age, Geophys. Res. Lett., 27(20), 3365-3368, 2000.

$\mathrm{Xu}, \mathrm{X}$.: Investigations into the tropospheric cycle of COS: Atmospheric distribution, air-sea and air-vegetation exchanges, Dissertation, Universität in Frankfurt am Main, Frankfurt, Germany, 2000.

$\mathrm{Xu}$, X., Bingemer, H. G., and Schmidt, U.: The flux of carbonyl sulfide and carbon disulfide between the atmosphere and a spruce forest, Atmos. Chem. Phys., 2, 171-181, 2002, http://www.atmos-chem-phys.net/2/171/2002/.

Yvon-Lewis, S. A. and Butler, J. H.: Effect of oceanic uptake on atmospheric lifetimes of selected trace gases, J. Geophys. Res., 107(D20), 4414, doi:10.1029/2001JD001267, 2001.

Zielinski, G. A.: Stratospheric loading and optical depth estimates of explosive volcanism over the last 2100 years derived from the Greenland Ice Sheet Project 2 ice core, J. Geophys. Res., 100, 20937-20955, 1995. 